\title{
Mixed Conjunct Verbs And Other Manifestations Of Hindi Englishization
}

\author{
Tomasz Borowiak \\ Institute of Linguistics, Adam Mickiewicz University \\ ul. Międzychodzka 5, 60-371 Poznań
}

debelleme@poczta.onet.pl

\begin{abstract}
This article aims at describing some lexical exponents of English impact observed in the urban, colloquial variety of Hindi. At the lexical level of the language, the process of Hindi Englishization involves borrowing of lexemes representing major lexical categories and the formation of hybrid structures in which the borrowed and native morphemes meet. Accordingly, we will investigate some crucial aspects of English noun, adjective and adverb insertion, and further along discuss the mixed conjuct verbs, mixed postpositons and the affixation of the borrowed items.
\end{abstract}

\section{Introduction}

The Englishization of Hindi as first introduced by Kachru (1975) and developped in (1986a) has in recent years received little attention from scholars As a matter of fact, no in-depth studies have been made in the field since the 1980's. Needless to say, more novelties have occured and other linguistic processes of Englishization have appeared that as yet have not been attested in the literature on HindiEnglish contact phenomena. These linguistic innovations supported by recently gathered data are thus voiced in this study. ${ }^{1}$

\section{Data gathering}

The data for this research consists of internet newspaper excerpts, along with samples from Indian film and radio speech. Newspaper articles (in a total number of one thosand) come from the internet versions of India's major dailies, Amar Ujālā (August 2003 - August 2006) and Navbhārat Times (Sept 2006 - June 2007). The source of the radio samples is the Deutsche Welle's Hindī Käryakram (Hindi Service). Two daily 30-minute programs were analyzed during March-June 2007 period providing research material of one hundred twenty hours. Notwithstanding the fact the Deutsche Welle represent formal register of Hindi speech, a fair amount of English or Englishized items were obtained

\footnotetext{
${ }^{1}$ Some features of Englishization were briefly discussed by Bhatia \& Ritchie (2005: 798-799). Here they claim the mixing with English has resulted in introduction of 'a new class of transitive/caustive verbs of mixed type', e.g. STUDY karnā, TEACH karvānā, that according to the authors 'are not just a paraphrase of translational equivalent of Hindi'. However, in our view, these examples of hybrid constructions are not new instances of hybridization, but similar, if not identical, to those that have already been discussed in Kachru (1975) and (1986a).
} 
to a different extent, from the English originals. While others, borrowed more recently, lack this phonological adaptation and when considered in isolation, due to their English phonological shape, would be classed by many native speakers as English items. Some nouns e.g. hospital can be pronounced in two ways, as an established borrowing (aspatāl) or as an originally English word (hospital). The acceptance of loans in something approaching their original shape is by no means uncommon among bilinguals that are literate in several languages. Yet, whatever phonological variation, they are used as Hindi items since they obey Hindi grammatical rules. 2

Furthermore, the nouns embedded show varying degree of accordance with Hindi grammar. Some items fully adapt to the grammatical structure, and others to a lesser extent. Nonce borrowings, for instance, normally do not fully follow the grammatical rules. The following are illustrative.

(1) ab yeh to bolivud stạrõ kī shurūse paramparā rahī now 3.SG-DEM ${ }^{3} \quad$ GEN-f beginning from tradition remain-SIMP-PERF-f that From the start it has been the tradition of Bollywodod stars to (...)

(AU 12/10/05)

(2) sallu ke sabhī dostõ aur CO-STARS ne unhẽ shubhkāmnā sandesh diye. (name) GEN-m-PL every EMPH friend-PL-OBL and ERG 3.PL-HON-DAT wish send-give SIMPPERF

All Sallus'friends and co-stars have given (expressed) [best] wishes to him.

(NBT 17/06/07)

(3) baṛe dāyrekțarhaĩ aur bare ko-sțār haĩ.

great-PL be-PRES-PL and great-PL be-PRES-PL

[They] are great directors and great co-stars.

(AU 12/04/04)

In example (1) the noun star fully complies with Hindi grammar and behaves as a regular Hindi noun, the suffix of the oblique case ' $\tilde{\mathrm{o}}$ ' is added to the borrowed noun, as required by the following postposition. In sentence (2) both nouns are also followed by the ergative postposition ne and need the oblique case inflections as well. However, the Hindi noun dost (friend) obeys the rule, while the English co-stars does not. In (3) the plurality of the nouns is expressed by the plural verb and the adjectives that inflect for gender and case of the head nouns, and not by the English plural marker 's'. This is especially surprising when one considers that the plural form of co-star, as in sentence (2), is admissible in mixed Hindi. Factually, in numerous examples, both English and Hindi plural markers are employed with borrowed nouns.

Another thing to observe is that all the English nouns embedded into mixed Hindi are assigned gender,vmasculine or feminine. The number of the inserted nouns can be both singular $(9,10)$ and plural (11). Two nouns can be embedded on noun+noun basis, with $(12,13)$ or without the Hindi

\footnotetext{
${ }^{2}$ As Haugen (1950: 222) reports some items may be borrowed twice at different times. He referred to this phenomenon as a 'reborrowing'.

${ }^{3}$ The following abbrevaitions are used throughout this article:

$\begin{array}{llllll}\text { ABS } & \text { absolutive participle } & \text { CAUS II } & \text { double causative } & \text { COMP } & \text { comparative } \\ \text { DAT } & \text { dative } & \text { DEM } & \text { demonstrative } & \text { EMPH } & \text { emphasis } \\ \text { ERG } & \text { ergative } & \text { f. } & \text { Feminine } & \text { FUT } & \text { future } \\ \text { GEN } & \text { genitive } & \text { HAB } & \text { habitual tense } & \text { HON } & \text { honorific } \\ \text { m. } & \text { masculine } & \text { NEG } & \text { negative } & \text { NONOBL } & \text { non-oblique } \\ \text { OBL } & \text { oblique case } & \text { PERF } & \text { perfective } & \text { PL } & \text { plural } \\ \text { POSSESS } & \text { possessive } & \text { PRES } & \text { present } & \text { PRESUMPT presumptive } \\ \text { PROG } & \text { progressive } & \text { REFL } & \text { reflexive } & \text { REL } & \text { relative } \\ \text { SG } & \text { singular } & \text { SIMP } & \text { simple } & \text { SUBJ } & \text { subjunctive }\end{array}$
}


genitive postposition $(14,15)$. The phrasal noun insertion occurs as well $(16,17)$. The examples are given here.

(4) mere pās ek dūsrā ceñj hai.

1.SG.POSSESS-OBL near one another be-PRES

I have got another [clothes for] change.

(PHIR MILENGE)

(5) ismẽ SHAME kī kyā bāt hai?

3.SG-DEM-OBL-in GEN-f what matter be-PRES

What is shame[ful] in it?

(JULIE)

(6) unhõne mujhse pūchā ki tumhārī PREPARATIONS kaisī haĩ?

3.PL-HON-ERG 1.SG-DAT ask-SIMP-PERF if 2.PL-POSSESS how be-PRES-PL

He asked me how [far] my preparations were.

(PHIR MILENGE)

(7) dịzāins $k \bar{\imath}$ PRESENTATIONS usne kī thī.

GEN-f 3.SG ERG do-PERF-PAST

He has done the presentations of the designs.

(PHIR MILENGE)

(8) āpne hamāre progrām ke ADS mẽ dekhā hogā.

2.PL-HON-ERG 1.PL-POSSESS GEN-m in see-PERF PRESUMPT

You have [probably] seen the ads for our programs.

(JULIE)

(9) yeh film unke CAREER ke lie TURNING POINT hogī.

3.SG-DEM 3.PL-HON for be-FUT-f

This will be a turning point in his career.

(AIR 10/08/03)

(10) donõ taraf $k \bar{a}$ ear preshar EQUALIZE hotā hai.

both side GEN-m

be-HAB PRES

The air pressure of both sides gets equalized.

(AIR 19/07/03)

(11) havā̄ jahāz safar karte vaqt laindịng aur țekäf ke samay (...) plane journey doing time and GEN-m time

While travelling by plane, during landing and taking off (...)

(AIR 24/07/03)

(12) maĩ lok ap mẽ hũu.

1.SG. in be-PRES

I am in a lock-up.

(CHAMELI)

There have been recorded in the data several cases of substantivization. For instance, English expression in charge that has been substantivized as in (13)

(13) mai is kes ka iñcarj hũ .

1.SG 3.SG-DEM-OBL GEN-m be-PRES

*I am the 'in-charge' of this case.

(ZURM) 
One may claim this sentence is a mere example of loan translation of English expression be in charge $o f$. The presence of the genitive postposition 'kā' that functions that functions as a kind of adjectival modifier in agreement with in-charge serving as a noun, certainly excludes this assumption.

\subsection{Fully adapted vs. partially adapted nouns}

It is clear that in any language-contact situation, linguistic units of the donor language when incorporated in the RL normally undergo adaptation in order to fit its grammatical structure. As for English-Hindi specifically, it is the noun that shows the greatest adaptative qualities out of all word categories rendered into the colloquial variety. In this section we discuss the stages for a foreign nominal to come through to become fully integrated into the recipient language.

Apparently there are three different stages in the adaptation process to be distinguished. In the first one, the foreign item is embedded into mixed Hindi on ad hoc basis, so it is a nonce borrowing. The lexeme obeys Hindi gammatical rules, but its plural is formed only by foreign means, i.e. by adding -s [-z] suffix. The next stage shows greater integration, as both Hindi $\varnothing$ and English -s markers are commonly observed to produce plurals. As soon as $\varnothing$ marker is found adjoined to the loaned nominals, the way is open for the addition of plural oblique case markers as well. Finally, oblique, and in a case when a particular item fits certain declensional type, also non-oblique suffixes are observable. At this stage the loans are already morphologically indistinguishable form native nouns.

1. Adaptation in plural non-oblique and oblique forms of nouns assigned to feminine gender (final vowel -ī) Examples are as follows.

\begin{tabular}{|c|c|c|c|}
\hline AGENCY & ejansī & ejansiyã & ejansiyõ \\
\hline FANTASY & faintesēi & faintesiyã̃ & faintesiyõ \\
\hline FACULTY & fakalțī & fakaltiyã & fakaltịoõ \\
\hline FREQUENCY & frīkvens̄̄ & frīkvensiyã & frīkvensiyõ \\
\hline FACTORY & faiktrī̄ & faikțriyã & faiktriyõ \\
\hline GALAXY & gailaksī & gailaksiyã & gailaksiyõ \\
\hline POLICY & pālisī & pālisiyã & pālisiyõ \\
\hline TANK & țankī & țankiyã & țankiyõ \\
\hline
\end{tabular}

2. Adaptation in plural non-oblique and oblique forms of nouns assigned to feminine gender (consonant endings)

\begin{tabular}{|c|c|c|c|}
\hline FILE & fāil & fāilẽ & fāilõ \\
\hline GAS & gais & gaisẽ & gaisõ \\
\hline HEROINE & hīroin & hīroinẽ & hīroinõ \\
\hline MISSILE & misāil & misāilẽ & misāilõ \\
\hline PLATE & plet & plețẽ & plețô \\
\hline SCRIPT & skript & skripțẽ & skripțõ \\
\hline SEAT & sìt & sītễ & sīṭõ \\
\hline TEAM & tìm & țịmẽ & țīmõ \\
\hline
\end{tabular}

3. Adaptation of nouns assigned to masculine gender (I declensional subtype)

$\begin{array}{llll}\text { SOFA } & \text { sofā } & \text { sofe } & \text { sofõ } \\ \text { CAMERA } & \text { kaimerā } & \text { kaimere } & \text { kaimerõ } \\ \text { FORMULA } & \text { fărmyūlā } & \text { fărmyūle } & \text { fārmyūlõ }\end{array}$

\section{Adjective insertion}

Let us now turn our attention to adjective borrowing. Well, the data demonstrates that there are a number of patterns of adjective insertion into mixed Hindi. The two most common involve single item 
insertion that modifies the Hindi noun, as in (14) and (15), and the insertion of phrases in which case the adjectives are inserted together with the English noun as in (16), (17) or adverb (18), (19). This is unsurprising. Sankoff (1998: 19) states that '[i]f nouns are often borrowed and adjectives are often borrowed, then occasionally a noun-adjective combination will appear to have been borrowed together'. Similarily as the Hindi adjectives, the loans can be used predicatively as well $(20,21)$. Some gradable adjectives are imported readily in a comparative form, but comparative (22) and superlative (23)constructions for English adjectives can also be formed by means of Hindi. The borrowed adjectives are indelinable, and behave as the indeclinable subgroup of Hindi adjectives, e.g. zinda (alive), barhiya $\bar{a}$ (nice) etc., thus in this respect do not introduce any grammatical novelty.

(14) kisī aur kī galtī ke lie apnī jān denā kō̄ SENSIBLE bät hai ?

some other GEN-f mistake for REFL-POSSESS life give-VN some matter be-PRES

Is it sensible to sacrifice own life for somebody else's mistake?

(JULIE)

(15) chillāne kī kyā zarūrat hai, normal tarīke se bāt nah̃̃ kar sakte haĩ?

scream-OBL GEN-f what necessity be-PRES way with talk NEG do can-PRES-PL

Why do you scream? Cannot we talk normally?

(ZURM)

(16) rediyo kā REGULAR LISTENER hĩ maĩ.

GEN-m be-PRES 1.SG

I am a regular radio listener.

(AIR 12/07/03)

(17) maĩ HIV-RELATED CASES ke bāre mẽ zyādā nah⿱一兀) jāntā.

1.SG about much NEG know-PRES

I do not know much about HIV-related cases.

(PHIR MILENGE)

(18) aur ye ROCKS TOTALLY DARK haĩ.

and 3.PL be-PRES-PL

And these rocks are totally dark.

(JULIE)

(19) lekin hamārā cainal sirf COMMERCIALLY VIABLE nahĩ hai (...)

but 1.PL-POSSESS only NEG be-PRES

But our channel is not only commercially viable (...)

(JULIE)

(20) yeh patr ADDRESSED hai FM ke lie.

3.SG-DEM letter be-PRES for

This letter is addressed to FM (radio station)

(AIR 17/07/03)

(21)I KNOW merā savāl IRRITATING hai.

1.SG-POSSESS question be-PRES

I know my question is irritating. 
(22) isse BETTER yā aur INTERESTING TOPIC hai āpke pās?

3.SG-OBL from or COMP be-PRES 2.PL-HON near

Do you have a better or more interesting topic than this one?

(HUM TUM)

(23) riyā sen ko ashmit pațel sabse seksī dikhte haĩ.

(name) DAT (name) SUPERL look -PRES-HON-PL

For Riya Sen Ashmit Patel is the most sexy guy.

(AU 16/05/04)

Furthermore, among other distinct features observable in the data, there are e.g. non-standard prefixation and the particle '-sā' suffixation. The first refers to atypical and non-standard creation of adjectives having the opposite meaning, e.g. safe - insafe rather than unsafe, insecure; traditional intraditional rather than untraditional. The latter involves adding to English adjectives the particle denoting a moderate degree of a quality, e.g. NATURAL-sā, SMART-sā.

\section{Adverb insertion}

In Standard Hindi adverbs are very few in number. Kachru (1980: 78) argues that most words are called adverbs because they function as such category. In fact, very few items are basically adverbs, (e.g. acānak, suddenly; dhyānpürvak, carefully). Occasionally, in forming basic adverbs, Sanskrit suffix 'tah' and inflectional ending 'yā' are used. In most sentences, however, adjectives (e.g. acchā 'good', sundar 'beautiful') or nouns followed by a postposition function as adverbs (e.g. mushkil se, 'with difficulty'; $\bar{a} s \bar{a} n \bar{\imath}$ se 'easily').

English adverbs, in turn, constitute a considerable number of lexical items borrowed into mixed Hindi. In most cases they modify the Hindi verb or adjective $(24,25)$ though in longer insertions they can modify English verbs and adjectives as well. Hybrid adverbs consisting either of English noun and Hindi postposition or Hindi adjective/noun followed by an English adverb forming suffix '-ly' were as yet absent in the data. ${ }^{4}$ In some sentences, the position of adverbs (e.g. initial, final) in the phrase or sentence is clearly influenced by English (26) to (28). A few examples of borrowed adverbs are given below.

(24) tum log fulī pāgal ho, thīk hai maĩ āũ $\bar{a}$.

2.PL people crazy be-PRES, ok be-PRES, 1.SG come-FUT

You are completely crazy, [but] ok, I will come.

(JULIE)

(25) tumne apnā phon ān chor diyā.

2.PL-ERG REFL-POSSESS leave-give-SIMP-PERF

You have left your phone on.

(MASTI)

(26) enive, maĩne apnī OBJECTIONS promo dạyrakțar ko bhej dĩ. 1.SG-ERG REFL-POSSESS DAT send give-SIMP-PERF-f-PL

Anyway, I have sent my objections to the promo-director.

(27) subah SIR kī kō̄ kols āye, phir vah fäinal̄̄ mere ghar par cale āye,

morning GEN-f few come-SIMP-PERF-PL, later 3.SG 1.SG-POSSESS house on come-comeSIMP-PERF-HON-PL

He called me a few times in the morning, and finally came to meet me at my

\footnotetext{
${ }^{4}$ As reported by Shapiro (2003: 266) in formal Perso-Arabicized registers single word adverbs are found that incorporate adverbforming suffixes in Persian and Arabic respectively, e.g. ittifāqan 'by chance' (ittafāq 'chance' + an).
} 
mujhse milne.

1SG with meet-OBL

house.

(PHIR MILENGE)

(28) mujhe hospital jānā hai, arjențlì.

1.SG-DAT go-VN be-PRES

I must go to the hospital urgently.

\section{Conjunct verbs}

In Standard Hindi, conjunct verbs are very common. These constructions form a single syntactic unit and are used to express notions that in other languages are expressed by a unitary verb. Typically, they consist of:

(i) a noun followed by a verb, e.g. ārambh karnā 'start do' - to start, intazār karnā 'wait do' - to wait, anumati denā 'permission give' to permit, safāi karnā 'cleanness do' to clean, etc.

(ii) an adjective followed by a verb, e.g. nishcit karnā 'sure do' - to make sure, pareshān karnā 'worried do' - to cause anxiety', pūrā karnā 'complete do' - to finish, to complete, mālüm karnā 'known do' to discover, to ascertain, spașt karnā 'clear do' to make clear, to explain, săf karnā 'clean do', to clean, etc.

Conjuncts based on nouns are far more numerous than those based on adjectives. Among the verbal components of the conjunct constructions, the most popular are the verbs hon $\bar{a}$ 'to be' and karn $\bar{a}$ 'to do', forming verbal expressions, intransitive and transitive respectively, though other verbal elements such as den $\bar{a}$ 'to give', len $\bar{a}$ 'to take', $\bar{a} n \bar{a}$, to come', lagann $\bar{a}$ 'to join, to connect, to fasten, to apply' are used as well. Other patterns, e.g. a verb followed a verb, or an adverb followed by a verb, do not occur in the Standard Hindi.

As previously attested (Kachru 1978, 1986a) many English-origin words associate with the Hindi verbs to form the conjunct constructions in code-mixed utterances. However, in mixed Hindi, conjunct verbs are patterned differently than in the the standard variety. These patterns of mixed conjunct verbs (onwards MCV) include 1. 'nominal' conjuncts, 2. 'verbal' conjuncts, 3. 'adjectival' conjuncts, as they are proposed here to be termed. The utterances in which the MCV are employed prove the MCVs to behave identically as in non-mixed constructions.

\subsubsection{Nominal conjuncts}

In this pattern, an English-origin noun is followed by a Hindi verb, e.g. OFFER dena ' 'offer give' = to make an offer, to offer, CONFIRMATION karna ' 'confirmation do' = to confirm, CASE karna ' 'case do' $=$ to put the case, PAINTING karnā 'painting do' = to do painting, PREPARATION karnā 'preparation do' = to make preparations, PRESENTATION karnā 'presentation do' = to have a presentation. For the sake of convenience, all foreign verbal components have been given in capital letters.

(29) hamāre sho ko lekar kāfì CRITICISM ho rahī hai. 1.PL POSSESS DAT take-ABS quite be-PROG-PRES

There's quite a lot of criticism going on of our show.

(30) yeh ham ne bare flaițs mẽ bhī mārbal se zyādā impārțans dī hai spes ko.

(JULIE) 3.SG-DEM 1.PL-ERG big in even from more give-PERF PRES DAT In big flats we have given even more importance to space than to marble.

(31) mujhe ecāivì kī infekshan ho jāẽ to ? 1.SG-DAT GEN-f be go-SUBJ then What if I got HIV infection? 


\title{
7.1.2. Compound noun based MCVs
}

$\mathrm{N}+\mathrm{N}$ based MCVs are a subgroup of the nominal type. Data shows these occur quite frequently, e.g. bam-blāst karnā 'bomb blast do', gud morning karnā 'good morning do', peparvark karnā 'paper work do', pres kānfarens karnā, 'press conference do' biznas plān karnā, 'to make a business plan', etc. as in the following :

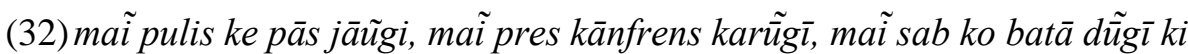
1.SG near go-FUT-f, 1.SG do-FUT-f, 1.SG everybody DAT tell give-FUT-f that I will go to the police, I will do a press conference, I will tell everybody that

usne usko mārā. 3.SG-ERG 3.SG-DAT kill-SIMP-PERF she has killed him.

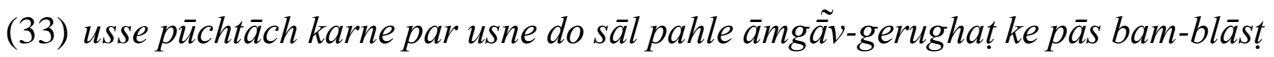
3.SG with inquiry do-OBL on 3.SG-ERG two year before (name) near When questioned, he admitted [involvement in] a bomb blast near Amgav-

\author{
karne kī ghațnā kabūlì. \\ do-OBL GEN-f event accept-SIMP-PERF \\ Gerughat two years before.
}

(HINDI GOOGLE)

(34) ham sabhī kisī na kisī rūp mẽ peparvark karte haĩ, jo bahut zarūrī hai.

1.PL everybody-EMPH some-NEG-some shape in do-PRES, that-REL very important be-PRES Every single one of us does some kind of paperwork that is important.

(JAG 27/09/06)

\subsubsection{Verbal conjuncts}

These are formed by an English verb followed by a Hindi verb as in ATTEND karna 'attend do' = to attend, CONSIDER karnā 'consider do' = to consider, NORMALIZE hon $\bar{a}$ 'normalize be' = to normalize, etc. With verbal conjuncts, the Hindi transitive verb karnā is used the most often, though instances of intransitive hon $\bar{a}$ have also been observed. As a matter of fact, one can predict that similarily to non-mixed expressions, both verbs are possible for each and every mixed construction. Out of all patterns of producing MCVs, verbal conjuncts, rank first in terms of frequency. This is particularly interesting, as this pattern is non-existent in the standard variety.

(35) kyā āpne MR sharmā ko apne ABSENCE ke bāre mẽ INFORM kiȳā? what 2.PL-HON-ERG DAT REFL-POSSESS about do-SIMP-PERF Did you inform Mr Sharma about your absence?

(36) pahle khud apne āpse DISCRIMINATE karnā band kar, phir dūsrõ se EXPECT (PHIR MILENGE) karnā.

first REFL-POSSESS 2.PL-HON-DAT do-VN finished do-ABS, then other-PL-OBL from First, don't discriminate yourself, then expect the same from others.

(PHIR MILENGE)

(37) ve CONSIDER kar rahe haĩ ki apne sāre prādakts dūsrī ejansī ke pās le jāẽe. 3.PL do-PROG-PRES that REFL-POSSESS all-m another They are considering taking all their products to another agency. near take go-SUBJ 
(38) maĩne tumhẽ pārțī kā nām red pensil se andarlāin karne ko bolā thāa.

1.SG ERG 2.PL DAT GEN-m with do-OBL DAT tell-PERF-PAST

I have told you to underline the party's name in red pecil.

(AIR 15/08/03)

(39) maîne kal jo lețar tumhẽ țāip karvāyā thā, usmẽ ākhir mẽ

1.SG ERG yesterday which-REL 2.PL DAT do-CAUS-II PAST, 3.SG-DEM-OBL in end in

When I had the letter typed yesterday, I wanted you to write 'with regards' in

$$
\begin{aligned}
& \text { likvāya "WITH REGARDS” aur tumne țāip kiyā "WITH LOVE” } \\
& \text { write-CAUS-II-SIMP-PERF and 2.PL ERG do-SIMP-PERF } \\
& \text { the end, but you had typed 'with love'. }
\end{aligned}
$$

(AIR 15/08/03)

(40) āpkī kampanī ke sels 56 PERCENT se IMPROVE hue...

2.PL-HON-POSSESS GEN-m-PL with be-SIMP-PERF-PL

The sales of your company have improved by 56 percent.

(PHIR MILENGE)

(41) peris ke bād kyā tum mumbaī mẽ mere sāth ADJUST kar pāogī?

after what 2.PL Mumbai in 1.SG-POSSESS with do manage-FUT-f

After Paris, will you be able to adjust with me in Mumbai ?

(HUM TUM)

\subsubsection{Adjectival conjuncts}

The adjectival conjuncts in mixed Hindi are a third largest group of MCVs after structures having nominals and verbals as bases. When inserted into Hindi matrix, initially they produce intransitive constructions of $\mathrm{ADJ}+$ hon $\bar{a}$, where the verb be acts as a copula. As the integration progresses the forms $\mathrm{ADJ}+$ karnā also appear.

It is important to note that while V-based or N-based MCVs can be created in an unconstrained manner, just by sheer insertion of foreign element and joining it with native verbal component, the ADJ-based are not so freely formed. In most cases, in order to produce an adjectival conjunct the item has to be nativized, which is not the case with nominal and verbal structures. They occur with high frequency in non-assimilated code-mixe speech, but the ADJ-based do not. In other words, we can argue that basically any English noun or verb may form MCVs in mixed Hindi, while it is not so in adjectival conjuncts. Moreover, it seems that some English-origin adjectives are less susceptible to produce MCVs, with the exception of ADJ+hona structures mentioned above. Among them are interested, excited, busy, self-centered, unfaithful, etc. These have not been so far observed to form MCVs with karnā as a constituent, although they are in fact very common with hon $\bar{a}$, as data demonstrates. Below are some examples in which karnā does occur.

(42) bīmārī kī jar mānī jānevālī shugar ab māiṇ ko shārp karegī. illness GEN-f origin believed go-vālā-f now DAT do-FUT-f Sugar that is believed to cause the illness will make the mind sharp.

(NBT 09/07/07)

(43) kō̄ xabar yā fonkol āpkā mūd fresh kar saktī hai. some news or 2.PL-HON-POSSESS do can-PRES Some piece of news or a phonecall can freshen your mood. 
(44) unko avayer karnā nihāyat zarūrī hai.

3.PL DAT do-VN extremely necessary be-PRES

It is extremely important to make them aware [of it].

(NBT 12/07/07)

(45) apne prodakt ko popular karne ke lie kampaniy ã use saste dāmõ

REFL-POSSESS DAT. do-OBL for company-PL-NON-OBL 3.SG-DAT cheap price-PL-OBL

To make their product popular, the companies also sell it for

\author{
par bhī bec detī haî. \\ on also sell give -PRES \\ cheap prices.
}

(AU 07/10/05)

\section{Mixed postpositions}

Hindi is rich in postpositions which are used to indicate different syntactic functions served by nouns. Due to the Englishization process, apart from Hindi-only postpositional expressions mixed Hindi and English structures are employed bymixed Hindi speakers as well and thus a number of new expressions are added to the mixed Hindi linguistic repertoire.

The vast majority of these compound postpositions consist of two elements with the first one ke/ki present in both mixed and non-mixed varietes, but the second one being replaced in mixed Hindi by its English equivalent. For example, ke xiläf turns into ke OPPOSITE, ke dvārā into ke THROUGH.

(46) FRANCE kī jantā ne 2002 mẽ Le Pen ke AGAINST voṭ kiyā thā GEN-f population ERG in do-PERF-PAST In 2002 [election] the French population voted against Le Pen.

(DW 14/06/07)

(47) iskī help se_varḍ lisț, flaish kārds, maiths kī kvik tips hāsil kar sakte haĩ. 3.SG-DEM-OBL with GEN-f get do can-PRES-PL

With the help of [the tool] you can get[acess to] the word list, flash cards and quick tips on maths.

(NBT 18/04/07)

(48) ham ummīd karte hai ki äpko acche-sacce dost FM ke thrū_zarūr milège.

1.PL hope do-PRES hat 2.PL-HON-DAT good-true friend We hope you can find good friends via/through the FM [radio] surely meet-FUT-PL

(AIR 17/07/03)

\section{Affixation}

The unit hybridization in Kachruvian sense manifests in the affixation. Lexemes rendered from English are suffixed or, by lesser extent, prefixed by Hindi morhemes, both content and grammatical. This particular kind of unit hybidization differs from other types e.g. conjuncts and mixed collocations, as it takes place within a single lexeme. There are four distinguished patterns of unit hybridization recorded in the data and they are as follows,.

1) imported English stem affixed by Hindi grammatical morpheme '-õ' - plural oblique case suffix 


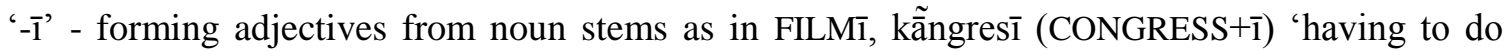
with congress' dạakțarī (DOCTOR+ $\overline{1})$ 'medicine, medical science' kaptānī (CAPTAIN+ 1$)$ 'captaincy'; afsarī (OFFICER $+\overline{1})$ 'duties of an officer'

'-iyat' employed to create abstract nouns as in haindsamiyat, i.e, HANDSOM+iyat :

jab âp lensas pahante haĩ to āpkī haindsamiyat chip jātī.

afsariyat (OFFICER+iyāt) officialdom

boriyat (BORE+ iyāt)

àj ravivār ko ghar par baiṭhnā āpke lie boriyat kā saba ho jātā hai.

2) imported English stem affixed by Hindi content morpheme

'-kār' -that forms agent nouns from nominal stems as in FILMkār darshakõ ne hī nahĩ , sāre bare filmkārõ ne mujh par vishvās kiyā

'-dān' -having the sense 'container of or for...' as in VOTEdān

'-ānkan' -as in FILMānkan shirșak gìt kā filmānkan lajavāb rahā hai.

'-dātā' -as in VOTEdātā

'-ānā' -as in FILMānā, afsarānā (bueraucratic, official) from (OFFICER+ānā) sunā hai ki ek barāa hissā ek eyarporț par filmāya gay $\bar{a}$

'-tầ' forming abstract nouns as in VOLTtā (volțtā) - voltage

'-shāh' afsarshāh (OFFICER +shāh) bureaucrat

'-shudā' rajisțīshudā (REGISTRY+shudā) registered

'-vād' forming -isms, sțālinvād (stalinism)

3) Hindi prefix followed by English stem

'be-' as in beTICKET (bețikaț)

4) English stem juxtaposed with Hindi stem, as in

karfyū-grast, i.e. CURFEW+grast $=$ affected by curfew (region) like durghātnāagrast karfyü-grast kșetr mẽ.

māigren pīrit, i.e. MIGRENE+ pīrit $=$ suffering from migrene duniyā bhar ke māigren pīritõ ko rāhat kī ummìd kī jā rahī hai.

dipreshan-grast, i.e. DEPRESSION+grast $=$ affected by depression sankat-grast (crisis)

fototo-sanshleșan i.e. PHOTO+ sanshleșan = photo synthesis

koch-vihīn, i.e. $\mathrm{COACH}+$ vihīn = deprived of a coach bhāratīya țīm shrī sharmā ke istīfe ke bād koch-vihīn hai.

misāil-rodhī, i.e. MISSILE+ rodhī = anti-missail misāil-rodhī vyavsthā.

\section{Conclusion}

In this article we have tried to show the Englishization process has far reaching effects on Hindi language and that it manifest in many linguistic phenomena. Some of them have been already attested in literature on the subject, but many of them have not. We have shown the most typical one, the mixed conjuct verbs, is rich in variety that has not been explored before. The given examples also prove the English influence has reached the morphological level of the Hindi language where the number of innovations have deeply changed its linguistic structure. As the Englishization is an evergrowing process we can expect more novelties to occur in the years to come. 


\section{Bibliography:}

Annamalai,E. 2001. Managing multilingualism in India - Political and Linguistic manifestations. Sage Publications, New Delhi

Bhatia, Tej K. and Ritchie, William C. (ed.) 2006. Handbook of Bilingualism. Blackwell Publishing

Haugen, E. 1950. The analysis of linguistic borrowing . Langauge 26, 210-231.

Kachru, Braj B. 1975. Toward structuring the form and function of code-mixing: an Indian perspective. Studies in the Linguistic Sciences, 5(1), 74-92. (A revised version, with the title "Toward structuring code-mixing: An Indian perspective," was reproduced in 1978 in the International Journal of the Sociology of Language, 16, 27-46).

Kachru, Braj B. 1983. The Indianization of English. The English Language in India. Oxford: OUP

Kachru, Braj B. 1986a. The Alchemy of English: the spread, functions and models of non-native Englishes. Oxford: Pergamon Press.

Kachru, Braj B. 1986b. English education in India: a sociolinguistic profile of Indian English. Nagoya Gakuin Daikagu Gaikokugo Kyoiku Kiyo No. 15:11-30.

Kachru, Yamuna. 1980. Aspects of Hindi grammar. New Delhi: Manohar Publications.

Malhotra, Sunita. 1980. Hindi-English Code-switching and Language Choice in Urban Upper-middle-class Indian Families. Kansas Working Papers in Linguistics vol 5. no 2. 39-46.

Sankoff, D. 1998. The production of code-mixed discourse. Proceedings of the 36th annual meeting on Association for Computational Linguistics 1, 8-21.

Sankoff, G. 2001. Linguistic Outcomes of Language Contact. In: Trudgill, P., Chambers, J. \& Schilling-Estes, N. (eds.) Handbook of Sociolinguistics. Oxford: Basil Blackwell, 638-668.

Singh, R. 1985. Grammatical constraints on codeswitching: Evidence from Hindi-English. Canadian Journal of Linguistics, $30,33-45$. 